\title{
Kuşlar Döndüğ̈̈̈nde: Jorge Semprun'un Büyük Yolculuk ve Yazmak ya da Yaşamak başlıklı yapıtlarında doğa ${ }^{1}$
}

\section{Çağrı EROĞLU²}

\begin{abstract}
APA: Eroğlu, Ç. (2019). Kuşlar Döndüğünde: Jorge Semprun'un Büyük Yolculuk ve Yazmak ya da Yaşamak başlıklı yapıtlarında doğa. RumeliDE Dil ve Edebiyat Araştırmaları Dergisi, (15), 470-478. DOI: $10.29000 /$ rumelide.580711
\end{abstract}

$\ddot{\mathbf{O z}}$

İspanyol yazar, senarist ve siyaset adamı Jorge Semprun'un (1923-2011) büyük kısmını Fransızca olarak kaleme aldığı yapıtları genel olarak, İspanyol İç Savaşı’ndan İkinci Dünya Savaşı sonrasına uzanan bir tarihsel düzlemde, XX. yüzyılın büyük siyasal olaylarını ve karanlık yüzünü ele alır. İspanyol İç Savaşı'nın başlamasının ardından 1937 yılında ailesi ile birlikte Fransa'ya göç eden, İkinci Dünya Savaşı sırasında Direniş hareketine katılan ve 1943 yılında tutuklanarak Buchenwald Toplama Kampı'na gönderilen Semprun'un 1963'te yayımlanan Le grand voyage - Büyük Yolculuk ile 1994'te yayımlanan L'écriture ou la vie - Yazmak ya da Yaşamak başlıklı kitapları yazarın kamp deneyimini aktarmalarının yanı sıra insana, yaşama, ölüme ve şiddete dair kapsamlı bir sorgulama sunarlar. Birbirini tamamlayan metinler olarak okunabilecek bu anlatıların önemli özelliklerinden biri anlatıcının yaşadığı olaylara, ruhsal ve bedensel değişimlere eşlik eden doğa betimlemelerine yer vermeleridir. Mevsimler, iklim, gökyüzü, ormanlar, nehirler ve kuşlar bir yandan anlatıcının yaşadıklarını anlamlandırması sürecinde yol gösterici olurlarken diğer yandan duygular ve zihin üzerindeki etkileri ve çağrıştırdıkları sonsuzluk, hüzün, acı, mutluluk, özgürlük gibi kavramlar çerçevesinden umut ile umutsuzluk, yaşam ile ölüm arasında gidip gelen bir deneyimin ve sorgulamanın etkileyici bir yazınsal metne dönüştürülebilmesine aracılık ederler. Bu doğrultuda, bu çalışmada, Büyük Yolculuk ile Yazmak ya da Yaşamak başlıklı yapıtlarda, insan-doğa ilişkisi kapsamında, travmatik bir deneyimin sorgulanması ve yazıya aktarılması sürecinde doğa betimlemelerinin üstlendikleri simgesel anlamlar ve rolün incelenmesi amaçlanmıştır.

Anahtar kelimeler: Jorge Semprun, İkinci Dünya Savaşı, travma, doğa, yaşam, ölüm.

\section{When birds come back: Nature in The Long Voyage and Literature or Life by Jorge Semprun}

\begin{abstract}
The works of author, scriptwriter and politician Jorge Semprun (1923-2011), most of which were written primarily in French, pertains to the highly political events and the dark side of $20^{\text {th }}$ century, covering the span from Spanish Civil War to the aftermath of World War II. Semprun fled with his family to France after the start of the Spanish Civil War in 1937, joined the French Resistance during World War II, for which he was arrested in 1943 and sent to Buchenwald Nazi Concentration Camp. Besides conveying the author's personal experience at the Camp, his novels The Long Voyage and Literature or Life -published in 1963 and in 1994, respectively- introduce an extensive analysis of
\end{abstract}

$1 \quad$ Bu makale, 26-27 Nisan 2018 tarihleri arasında Hacettepe Üniversitesinde düzenlenen XIII. Ulusal Frankofoni Kongresi'nde sunulan “Kuşlar Döndüğünde: Jorge Semprun'un Büyük Yolculuk ve Yazmak ya da Yaşamak Başlıklı Yapıtlarında Doğa” başlıklı bildirinin genişletilmiş biçimidir.

2 Dr. Öğretim Üyesi, Ankara Üniversitesi, Dil ve Tarih-Coğrafya Fakültesi, Batı Dilleri ve Edebiyatları Bölümü, Fransız Dili ve Edebiyatı Anabilim Dalı, eroglu@ankara.edu.tr, ORCID ID: oooo-0003-4672-9465 [Makale kayıt tarihi: 26.09.2018kabul tarihi: 18.06.2019; DOI: 10.29000/rumelide.580711] 
man, life, death and violence. One of the most important qualities of the narratives is the description of nature which accompanies the events and the physiological and psychological changes that the author has experienced. While the seasons, climate, the sky, the woods, the rivers and the birds guide the author to interpret what he has gone through, they also evoke concepts such as eternity, grief, pain, happiness and freedom, depicting an experience between life and death along with hope and despair. Thus, this paper aims at examining the figurative language and nature descriptions in the line of reasoning of a traumatic experience in the novels The Long Voyage and Literature or Life.

Keywords: Jorge Semprun, World War II, trauma, nature, life, death.

\section{Giriş}

İspanyol yazar, senarist ve siyaset adamı Jorge Semprun'un büyük kısmını Fransızca olarak kaleme aldı̆̆g yapitları, İspanyol İç Savaşı'ndan İkinci Dünya Savaşı sonrasına uzanan tarihsel süreçte XX. yüzyılın çalkantılı ve karanlık dönemlerine tanıklık eder. 1923 yılında Madrid'de doğan Semprun, iç savaşın başlamasının ardından ailesi ile Fransa'ya göç eder. İleriki yıllarda Paris'te felsefe eğitimine başlayan Semprun, 1941'de, Alman işgaline karşı silahlı direniş başlatan FTP (Les Francs-tireurs et partisans)'ye ve 1942'de İspanya Komünist Partisine katılır. 1943'te Gestapo tarafından tutuklanır ve siyasi tutuklu olarak Buchenwald toplama kampına gönderilir. 1945 yllında Paris'e dönen Semprun, 1952 yılına kadar Unesco'da çevirmen olarak çalıştıktan sonra, 1953’ten itibaren Franco rejimine karşı İspanya Komünist Partisi Merkez Komitesi tarafından örgütlenen direnişte yer alır ve ardından Merkez Komiteye girer. 1964 yılında görüş ayrılıkları nedeniyle partiden ihraç edilen Semprun, 1988-1991 yılları arasında İspanya Kültür Bakanı olarak görev yapar; yazar 2011'de Paris’te hayatını kaybeder.

Semprun, kamp deneyimini anlattığı ilk romanı Le grand voyage (Büyük Yolculuk)'ı, 1963 yllında yayımlar. Kamptan kurtulmasından yaklaşık yirmi yıl sonra, 1962'de kaleme aldığı bu ilk kitabın ardından 2010 yılına kadar yazmaya devam eder. Bu dönemde yazdıkları arasında, Quel beau Dimanche! (Ne Güzel Bir Pazar) (1980), L'Écriture ou la vie (Yazmak ya da Yaşamak) (1994) ve Le Mort qu’il faut (Gereken Ölüm) (2001), yazarın Buchenwald deneyimini anlatırlar.

Bu yapıtlar arasından Büyük Yolculuk ve Yazmak ya da Yaşamak, İkinci Dünya Savaşına dair tanıklık edebiyatının önemli örnekleri arasında yer alan özyaşamöyküsel anlatılar olmalarının yanı sıra, travmatik bir deneyimin yazıya nasıl aktarılabileceğini sorgularlar. Bu bağlamda, çalışmamızda ele alacağımız doğa, tıpkı sanat ve yaratıcılık gibi hem insani duyguları hem sürekli yenilenen bir yaşamı hem de insandan ve dolayısıyla otoriteden üstün bir gücü temsil etmesi açısından, Semprun'un tüm yaşamı boyunca kötülüğün yıkıcıllğına karşı yürüttüğü mücadelenin ve kötülüğün yıkıcı özünü ölümün diline dönüştürmeksizin aktarmasına aracılık eden yaratıcılığın beslendiği kaynaklardan birini oluşturur. Bunun yanı sıra doğa, bir yandan tanıklığının gücü "geçmiş olayların gerçekliğinde değil, onları anlama, anlatma isteğinde, canl tutma ve şimdiki zamanda var etme olanağı ve arzusu"ndan gelen yazarın deneyimini geçmişten geleceğe uzanan geniş bir zaman dilimine yayabilmesine olanak tanırken diğer yandan sunduğu tanıdık simgeler ve duygular aracılığıyla okuru için anlaşılması oldukça güç olabilecek bir anlatıyı anlaşılır kılar (Touret, 2004, 107) 3. Semprun'un metinleri zamandizinsel bir çizgi izlemeyen, çağdaş yazın tekniklerini kullanarak şimdiki zamandan geçmiş ve gelecek zamana atlamalar yapan ve bu atlamaların "tortusu dibe çöken su gibi zamanla saydam[laşmış]" bir belleğin çağrışımları aracılığıyla sağlandığı sinematografik anlatılardır (Gürsel, 1985, s. 231). Bu kurgu içinde doğa, zaman ve mekânlar arasındaki geçişleri yaratan bu çağrışımların tetikleyicisi görevini

Fransızca kaynaklardan yapılan çeviriler makale yazarına aittir. 
üstlenmesinin yanında metinlerin duygusal ve düşünsel yoğunluğunu güçlendiren ve yazıya dökülenin zamansal ve uzamsal sınırlarını belirleyen gerçekçi bir öğe olarak da karşımıza çıkar. Büyük Yolculuk ve Yazmak ya da Yaşamak'ta içerisi-dışarısı, ölüm-yaşam, tutsaklık-özgürlük diyalektiğine kıştan ilkbahara dönen mevsim, dondurucu karın yerini yeşeren ağaçlara bıraktığı orman, göğü kaplayan keskin duman kokusundan kaçan kuşların ağaçlarına dönme olasıllğı eşlik eder. Doğanın insandan bağımsız ve insana rağmen var olabilme gücü, yapıtlarda, geçmişte maruz kalınmış ve gelecekte de maruz kalınılabilecek kötülüğe karşı yaşamın üstünlüğünü ve gücünü savunan bir bakış açısının geliştirilmesine yardımcı olur.

Söz konusu yapıtlar, kampa gidiş yolculuğuyla başlayıp kampın kurtuluşundan itibaren artık bir "hortlağa" dönüşmüş olan tanık tarafından deneyimlenen ikinci yaşamı kapsayan geniş ve değişken bir zaman dilimine odaklanır (Semrun, 1998, s. 23). Semprun, 1995 yılında Elie Wiesel ile gerçekleştirdiği söyleşide, Wiesel'ın ifadesiyle karşısında "susma[nın] yasak, konuşma[nın] imkansız" olduğu böylesi bir deneyim hakkında, "hayatta kalabilmek için on beş yıl boyunca sessiz kaldr[ğımı]" belirtmiş ve unutmak ile anımsamak, susmak ve yazmak arasındaki farkı, unutmanın tedavi ediciliğine karşın yaşanılan deneyimi yok saymanın imkansızlığını, yazmanın yarattığı huzursuzluğu "yazmak hafizayı ve ister istemez iç sıkıntısın canlandırıyor. (...) Ve yazdıkça hafizam yerine geliyor, ama tabi ki de iç sıkıntım da canlanıyor" sözleriyle vurgulamıştır (Semprun ve Wiesel, 1995, s. 17-19). Semprun'un anlatılarını yönlendiren bir diğer soru kamp edebiyatının öncelikli sorgulama alanlarından birini oluşturan mutlak kötülügün dinleyicisini/okurunu umutsuzluğa düşürmeksizin nasıl aktarılabileceğidir. Dolayısıyla Büyük Yolculuk ve Yazmak ya da Yaşamak bir yandan deneyimlenen kötülüğün özünü yansıtırken diğer yandan söz konusu özün kültürel birikim, imgelem ve yaratıcılık aracılı̆̆ıyla yazınsal bir metinde nasıl sunulabileceğine örnek oluştururlar. Bu doğrultuda Semprun tanıklığını, kamp yaşamının içinde var olabilmesi olanaksız ancak tutsağın önceki yaşamını biçimlendirmiş ve gelecekte yaşama tutunmasını kolaylaştıracak kültür, sanat öğeleri ile dış dünyayı anlamlandıran ve insanın da parçası olduğu tüm canlı yaşamını kapsayan doğa ile zenginleştirir. Semprun kamp deneyimini aktarırken Kafka, Aragon, Malraux, René Char gibi yazarlardan alıntılar yapar, Renoir'ı, Picasso'yu, çeşitli şarkıları ve filmleri anımsar, Buchenwald'ın barbarlığının karşısına Goethe'in Weimar'ını koyar, firsat bulduğunda revirde refakat ettiği Maurice Halbwachs'ten, özellikle biraz serbest zaman bulabildikleri Pazar günleri kendi aralarında okudukları şiirlerden, Baudelaire'den, Rimbaud'dan bahseder 4 . Zira kültür, sanat ve edebiyat kamp yaşamında tutsakları saf kötülükten korur, "düşünme ve hayal etme becerisi bir koruma balonu" oluşturur ve hayatta kalma güdüsünün sürekliliğini sağlar (Benestroff, 2010, s. 42). Kamp yaşamını dayanılabilir kılan bu ögeler, sıra deneyimi yazıya aktarmaya geldiğinde ise "anlatıcı ve okuru anlatının zararl etkilerinden korurlar" (Benestroff, 2010, s. 51). Semprun'un yapitında da sinema, resim, müzik, heykel, edebiyat gibi farklı alanlardaki ürünleriyle sanat "kendisini oluşturanların uyruğu ya da dili ne olursa olsun kültürlerarası bir ă̆ kurar" ve "bu birlik, tutsakların içindeki insanh ğı, ki bundan mahrum brrakılmak istenmektedirler, güçlendiren özellikler üzerinde ısrarla durarak, otoriteye karşı bir direnç oluşturur" (Pedrol-Aguilà, 2016, s. 360). Semprun, Gérard de Cortanze tarafindan Jorge Semprun, L'écriture de la vie (Hayat Yazısı, Jorge Semprun) başlı̆̆ıyla kitaplaştırılan söyleşisinde, yazarlığının köklerini ve yaşam deneyiminin kitaplarındaki yerini “ ... özyaşamöyküsü tecrübem o kadar yüklü ki, sürekli özyaşamöyküsü anlatmaya bir eğilimim, bir isteğim hatta neredeyse öyle bir içgüdüm var. Kitaplarmm hemen hemen hepsi bitmek bilmeyen bir özyaşamöyküsü. Bu malzeme, sanki hiç tükenmeyecek gibi, tıpkı hafıza gibi” sözleriyle açıklar (Cortanze, 2008, s. 183). Yine aynı söyleşide Semprun, kampta geçirdikleri Pazar günlerinden Quel Beau Dimanche! (ilk basım Grasset et Fasquelle, 1980) / Ne Güzel
Bir Pazar ( çev. Can Utku, Everest, 2004) başlıklı yapıtında bahseder. 
Semprun, yaşamöyküsünün en belirleyici dönemini oluşturan kamp tutsaklığına dair deneyiminin yazıya aktarılmasında benimsediği temel yaklaşımı da özetler:

Aslında doğrudan tanıklktan yanayım ama, bu tanıklğın sanatsal bir hazırlıktan geçmedikten sonra huzursuz edici olabileceğini düsünüyorum. (...) Yazar yaratmak için orada. (...) Benim çok geniş bir seçici hafizam var. İzlenimleri, renkleri, imgeleri yeniden canlanderabilirim (Cortanze, 2008, s. 188).

Semprun, tanıklı̆̆ın, özellikle de toplama kampı deneyimi gibi anlamlandırılması, dillendirilmesi, sözcüklere dökülmesi ve bu deneyimi yaşamayanlar tarafından anlaşılması ve hatta inanılması oldukça güç bir deneyime dair birinci elden bir tanıklığın nasıl aktarılması gerektiğine ilişkin daha ayrıntılı bir değerlendirmeye Yazmak ya da Yaşamak'ta da yer verir. Yaşanılan deneyimin dillendirilemez olduğu iddiasını reddeden Semprun, tanıklığın yaşanılanın özünü koruyan ve bu özü okurca hissedilebilir bir biçimde sunan bir sanat ürününe dönüştürülmesi gerektiğini vurgular:

Yaşanan deneyimin dile gelmez oluşu değil söz konusu olan, 'yaşanamaz' oluşu... Herkes kolayca anlayacaktır ki bu hiç de aynı şey değil, tamamen başka bir şey. Yapılabilecek bir anlatının biçimiyle değil özüyle ilgili başka bir şey... Eklemlenmesiyle değil yoğunluğuyla ilgili... Bu öze, bu saydam yoğunluğa, ancak tankllkların bir sanat nesnesi, bir yaratı uzamı - ya da bir yeniden yaratma uzamı - haline getirebilenler ulaşacaktır. Ancak sanatçı denetiminde bir anlatının yapaylı̆̆ tanıklı̆̆ı doğruluğunu - kısmen de olsa - okura aktarabilecektir. (...) Her zaman her şey söylenebilir, dil her şeyi içerir. İnsan en çılgın sevgiyi de en korkunç kıyıcılı̆̆ da söyleyebilir (Semprun, 1998, s. 22).

Öte yandan tanıklığın sanatın ve yaratıcılığın süzgecinden geçmesi gerekliliğini açılkayan tek neden bu deneyimin okur tarafından kabulünün sağlanması değildir. Böylesi bir deneyim, öznesini yaşam ile ölüm arasında kaygan ve kırılgan bir uzamda yaşamaya mahkûm eder. Semprun kamp deneyimini “ölümü bir ucundan öbür ucuna [geçmek]", "ölümden, insanı değiştiren bir yolculuktan döner gibi dönmüş olmak" sözleriyle tanımlar (Semprun, 1998, s. 23). Dolayısıyla bu deneyime dair tanıklık yaşam ve ölüm arasındaki dengeyi doğru olarak kurabilmeli, yaşamın varlığını ve umudu yok saymayan, ölümün tarafına mahkûm olmayan özgün bir anlatı oluşturmalıdır:

[İnsan] Kötülüğü, onun afyon bitkisi tadını, kokuşmuş mutluluklarımı adlandırabilir. Tanrı’yı bile söyleyebilir insan, ki bu az şey değildir. Bir sabahlık sürede gülü ve çiğ damlasım söyleyebilir. Sevecenliği, herkesin sığınağı bu iyilik deryasın söyleyebilir. (...) Ama dönüp dönüp aynı şeyleri yinelemeye düșmek de var hesapta... İşin içinden çıkamamak, sırasında ölümü uzatmak, anlatının buruşuklukları ve katları arasında tekrar tekrar yaşatmak, sadece bu ölümün dili olmak, onun zararına yaşamak da var, ölümcül biçimde... (Semprun, 1998, ss. 22-23).

İşte bu noktada yazar yapıtının ortaya koyacağı saf kötülüğün de dilini oluşturan ölümün dilini, insanın yaratıcılığının en saf ve özgür dışavurumunu oluşturan sanat ve kültüre eklemlenen doğanın dili ile etkisiz kılmayı amaçlar. Sanat ve kültürden farklı olarak insandan bağımsız bir sürerliğe ve varolma gücüne, dahası insan yaşamı üzerinde mutlak bir etkiye sahip olan doğa böylelikle, insana özgü yıkıcı kötülükle mücadelede ve bu kötülügün dillendirilmesinde en önemli araçlardan birine dönüşür.

Büyük Yolculuk birbiri üstüne yığılmış gövdelerin ayakta durmakta, nefes almakta zorlandıkları, zaman kavramını yavaş yavaş kaybetmekte oldukları bir vagonda başlar. Direnişte Gérard ismini almış olan anlatıcının kurgusal yol arkadaşı Semur-en-Auxoislı delikanlı ile yan yana nereye götürüldükleri bilmeden ilerledikleri bu yolculuğa damgasını vuran ilk manzara karlar altındaki Moselle Vadisidir. Vagondaki ufak pencereden görünen vadi manzarası Gérard'a - Semurlu delikanlı yolculuğu sağ olarak tamamlayamayacaktır - kampa ulaşmadan önce, gelecek yllarda hayatta kalması için gerekli ilk yaşam bilgisini sunar. Kış ayazında, yüksek çamlara, şirin köylere ev sahipliği yapan, "yumuşak" ve "llık" duran 
bu vadinin temsil ettiği sonsuz yenilenme ve ölümsüzlük gerçeği, dışarıdaki yaşamın karşı tarafında, mahkûm edildiği içeride her an ölüm tehdidi altında olan yazarın geçmiş yaşamında bıraktıkları ile bağının kopmamasını sağlar (Semprun, 1985, s. 14). Böylelikle yazar doğanın koşulsuzca sunduğu yaşam olasılığını ve "yabanıl mutluluğu" gözden kaçırmayarak daha ilk andan hayatta kalmasını sağlayacak bir dayanağa sahip olur (Semprun, 1985, s. 15). Yazar, kamptan kurtuluşunun ardından çok defalar yeniden anımsadığı bu yolculuk ve manzaranın üzerinde yarattığı etkiyi şu sözlerle yorumlar:

\begin{abstract}
Yolculuğumuzun dördüncü gecesi. Her yanımızı yine o devinimsizlik duygusu kaplıyor. Gece çevremizde kımıldıyor. Devinen biz değiliz dünya. (...) bu gerçek dişına itilmişlik duygusunu ben değil, kendi dışımda gelişen olaylar yaratıyor. Yolculuğun hazırladığı olaylar. İyi ki arada Moselle Vadisi, o yumuşak, gölgelik ve sevecen Moselle Vadisinin karla örtülü gerçek varhğ geldi geçti. Orada yeniden buldum kendimi; beni ben yapan, beni doğal bir varlık, dayanışma, şiddet, başarı ve yenilgiden ibaret uzun bir tarihin sonucu, yani bir insan yapan Moselle Vadisi oldu. (...) İnsan organizması, canlı kalabilmek için gerçeğe tutunur" (Semprun, 1985, s. 70).
\end{abstract}

Öte yandan kar, Semprun'un yapıtlarında çoğunlukla Moselle Vadisindeki gibi muhteşem bir manzaranın hissettirdiği yabanıl mutluluğun parçası değildir. Semprun kamp edebiyatının en sık vurgulanan ortak imgelerinden ve kamp yaşamının ölümcül gerçeklerinden biri olan karın belleğindeki yeri hakkında şunları söyler:

Ben ilk gerçek karı, hani o Paris sokaklarında, çamura dönüşen siyahımsı kar gibi olanım değil, derin ve kahlcı olan karı, Buchenwald çevresindeki Thuringen Ormaninda fark ettim. Mesele bu kadar açık ve yalın. Aklımda kalan en güçlü imgelerden biri, hava karardığında, kampın projektörleri önünde uçuşan kar taneleri. Kar hattrası benim için ölümün hatırası (Cortanze, 20o8, s. 187).

Yolculuk boyunca Moselle Vadisini örten kar, yolculuğun sonunda, vadinin artık ulaşlamaz bir yerde kaldığı anda, Semprun'un karla ilgili yukarıda anımsadıklarını neredeyse birebir yansıtan bir betimlemede, bu defa ucuz bir yabanıllı̆̆ın tamamlayıcısı olur:

Çok sonraları, gürgen ve çam ormanları arasından kampın istasyonuna varışımız, belleğimin en uç, en gizli kalmış köşelerinden birinde öfkeli havlamalar ve parlak bir ışık demeti halinde çaktı. $O$ anı ne zaman anımsasam, seslerle ışık birbirine karışır, aralarında eşit bir denge kurulur. Havlayan köpeklerle karlı manzarayı aydınlatan projektörlerin soğuk ışığını birlikte algılarım (Semprun, 1985, s. 207).

Böylelikle kar, yazarın "canlıların dünyasından ayrılmak" olarak tanımladığı kampa giriş anından itibaren dışarının etkileyici gerçeği olmaktan çıkıp kampın yok edici gerçeğine dönüşür (Semprun, 1985, s. 223). Moselle Vadisinin yüksek çam ağaçlarının üzerinden görünen külrengi gökyüzü ise yerini üzerinde gerçekten küllerin uçuştuğu, fırın bacalarının dumanlarının bulanıklaştırdığı bir göğe bırakır. Kar artık taraf değiştirmiş ve ölümün yanında konumlanmış, yazarın ifadesiyle "Avrupa’nın üzerine çöken kış, demir ve ateş yağmuru”nun en tehditkâr unsurlarından birine dönüşmüsştür (Semprun, 1998, s. 34).

Büyük Yolculuk'tan otuz yl sonra, kamp deneyimini kampın kurtuluş günü olan 11 Nisan 1945’ten başlatarak aktaran Yazmak ya da Yaşamak ise, adı geçen romandan farklı olarak, kampta geçen sürede geleceği olası görünmeyen “masalsı nisan günü” üzerinden kurgulanır (Semprun, 1998, s. 24). Karın aksine ilkbahar, her zaman yaşamın tarafındadır. Kar, sessizliği ve soğukluğuyla tutsaklıktan kaynaklı devinimsizlik hissini güçlendirirken bahar, kış koşullarının kaçınılmaz sonucu olan durağan manzarayı hareketlendirerek umutsuz hüznün yerine umudun varlığına yer açan bir hüznü getirir. Büyük Yolculuk'ta tren yolculuğu sırasında olduğu gibi kamp yaşamına da damgasını vuran içeriye mahkûm 
olma, dışarıdaki dünyadan ve değişimden tecrit edilmiş olma hali baharın gelişiyle birlikte herhangi bir değişime uğramasa da, anlatıcının dış dünyayla kurduğu kısıtlı ve hüzünlü bağı korumasını sağlar:

İlkyazd, pazar günü herkes gezmeye çımıştı. Kimi zaman çocuklar da olurdu yanlarında. Çığllk çı̆̆lğa önden koşarlardı. Yol kenarındaki ilkyaz çiçeklerini koparmak için duran kadınlar da vardı. Orada, küçük korunun bittiği yerde ayakta durup dışarıdaki yaşamın görüntüleriyle kendimden geçerdim (Semprun, 1985, s. 25).

İlkbaharın gelişinin vurguladığı dış dünyanın gerçeğiyle, kamp yaşamının "doğallı̆̆ıı yitirmiş bir ölüm, bir cezaevi dünyası”ndan (Semprun, 1985, s. 70) ibaret gerçeği arasındaki keskin ayrım, kampın özgürlük anından başlayan Yazmak ya da Yaşamak'ta ilk olarak içerisi ile dışarısını ayıran eşikte belirir. Eteklerinde kurulduğu Ettersberg Tepesi'ni ve Weimar kentini bir zamanlar üzerinde Goethe'yle Eckermann'ın dolaştıkları topraklardan adeta bir cehenneme dönüştüren Buchenwald’in kurtarılışının hemen ardından baharın getirdiği umut ve ışık bu eşikten kampa sızar:

Albert'le ikimiz, içerinin pis kokulu loşluğu ile dışardaki nisan güneşini ayıran çizgide, taş kesilmiş duruyorduk. Karşımızda tek tük bulut parçalarıyla beneklenen duru mavi bir gök vardı. Küçük Kamp’n baraka ve çadırlarını ötesinde, yeşilin hâkim olduğu orman kütlesi çevremizi sarıyor, uzakta Thuringen dağları yükseliyordu. Başka deyişle, Goethe'yle Eckermann'in da Ettersberg Tepesinnde gezerken seyretmiş olabilecekleri ebedi manzaraydı önümüzdeki... (Semprun, 1998, s. 35).

Savaştan, insan eliyle kurgulanan yıkımdan bağımsız ilkbahar Ettersberg Tepesi'nde varlığını tüm gücüyle gösterirken Semprun'un ifadesiyle "tanımak için toplama kamplarnna gerek [olmayan] fakat [kamplarda] belirleyici ve kütlesel olan, geri kalan her şeyi kaplamış ve yutmuş" olan "kökensel kötülüğün" yarattığı "gündelik dehşet"in en simgesel izi olan duman da, firının kapanmasıyla yok olur (Semprun, 1998, s. 98-99). Fırının kapanması ve gökyüzünün daha ilk andan eski rengine kavuşması kamp yaşamının tutsakları mahkûm ettiği sessizliğin de kırılabileceği anlamına gelir. Bununla birlikte, mutlak kötülük kampla sınırlı değildir. Savaş boyunca kampı gören köylerinde günlük yaşamlarına hiçbir şey olmuyormuşçasına devam eden bölge sakinlerinin varlığı, yazarın insan doğasında var olan kötülüğü bir kez daha gözlemlemesine neden olur. Yazarın kampın kurtarılmasının hemen ardından yakındaki bir köyde dolaşırken düşündükleri kamp yaşamına özgüymüş izlenimi veren ve kampın ortadan kalkmasıyla yok olabileceği umut edilebilecek kötülüğün taşıyıcısı olan umursamazlığın ve duyarsızlığın kampın dışında da hakim olduğu gerçeğini gözler önüne serer:

Yalnızlk, Alman köyünün orta yerindeki çeşmeden su içtikten sonra da yakama yapışmışt. (...) Kamp tam önümüzdeydi şimdi. Yillarca köylülerin bize baktıkları yerden bakıyorduk kampa. Evet, kampl, orada olan biteni gördü köylüler, görmezlikten gelseler bile olup biten her şeyi kesinlikle gördüler. Amerikahlar, üç dört güne kadar Weimar'da oturan herkese kampı dolaşttracaklar. Karantinada, pis kokular içinde ölmeye devam eden sakatları gösterecekler onlara. Firın, SS doktorlarını tutuklular üstünde deney yaptıkları laboratuvarları, Bayan İlse Koch'un insan derisinden yapılmış abajurlarım gösterecekler. Parşömen kağıdı kadar ince derilerin üstündeki mavi nakışlara baktıracaklar. Bunun üzerine Weimarl kadınlar ilkyaz tuvaletleri, Weimarl erkekler bakkal ve öğretmen gözlükleriyle ağlaşmaya başlayacak, hiçkırlklarımı tutamayarak bütün bunlardan haberleri olmadığımı, bu barbarlıktan sorumlu tutulmamaları gerektiğini söyleyecekler (Semprun, 1985, s. 138).

Öte yandan, bu köyde yaşayanların aksine, geçen yıllarda dumandan ve Ettersberg’in üzerinde dört mevsim esen rüzgârın yaydığı ölüm kokusundan kaçmış olan kuşlar ise fırının kapanmasından kısa süre sonra ağaçlarına dönerler. Kuşların dönüşü, uzun kış ayları boyunca yerden kalkmayan kar örtüsünün daha da arttırdığı sessizliğin karşısına, yaşamın dönüşünü ve kötülüğün karşısında iyiliğin varlığını müjdeleyen cıviltıları çıkarır. Goethe’yle, Schiller'le, Alman anayasal demokrasisiyle özdeşleşmiş Weimar kentine insanın en karanlık yüzünün izini bırakan Buchenwald’in kapanması ve kuşların 
dönüşü, yazar için, Weimar’ın kültür kenti niteliğini ve tüm coğrafyanın ebedi manzarasını yeniden kazanmasının simgesidir:

- Kuşlar mı diye sordu Teğmen Rosenfeld bana dönerek. Şaşırdığı belliydi.

Sorgudan birkaç gün sonra, Ilm kıyısında, Weimar'n kapılarındayız. Goethe'nin yazın, serinlik ve yalnızhğın zevkini tatmak için çekildiği küçük kır evine doğru yürüyoruz.

Evet, kuşlar... Vadideki ağaçlarm dallarmda onlarm kalabalı ve gürültülü varlğ̆ı duyuluyor. Ötüşleri, civıltıları, bunların oluşturduğu karışık uğultu birden başıma vuruyor, yüreğim duracak gibi oluyor. Ancak duyulabilen varlkkları, göz kamaşstrıcı görünmezlikleri, o kadar yıllık buz kumultısi, buzların aniden çözülmesi gibi bir şey ...

[Teğmen Rosenfeld] Çevresine, Ilm kıyılarının büyüleyici manzarasına bakıyor. Irmağın aktığı fay çukuruna yukardan bakan şatonun yuvarlak gövdesi, barok saat kulesi görünüyor. (Semprun, 1998, s. 105).

Doğanın, yaşamın ve dolayısıyla insanlığın her ne olursa olsun eski haline dönebileceğinin ilk belirtisi olan berrak gökyüzü ve kuşların dönüşü yazarın yeniden başlayan yaşamının da ilk işaretlerini oluşturur. Ancak bu yaşam bu andan itibaren iki arada, tıpkı kampı terk etmeden hemen öncesinde olduğu gibi, bir yanı aydınlığa ve ebedi bir manzaraya öte yanı karanlık bir cehennem manzarasına açllan bir eşikte devam edecektir. Kamptan ölümün içinden geçmiş bir "hortlak" olarak dönen yazar için bu eşik aynı zamanda, kitabına da ismini veren yazmak ve yaşamak eylemleri arasındaki sınırı da belirler. Semprun için yaşamak kamp yaşamından uzaklaşmak iken yazmak belleğinde bu deneyimi yeniden kurgulamaktır. Mavi gökyüzünü yeniden görebilmiş yazar için yaşamın sunduğu tüm güzellik ve hazlar, deneyiminin unutulamazlığı ve yıkıcılığı karşısında etkisiz kalma tehdidi altındadır. Semprun'a göre her defasında yeniden ölümü deneyimlemeyi temsil eden yazma eylemi de bu eşikten başlar. Ettersberg Tepesi'ndeki karları anımsadığı her bir anda hissettiklerini betimlemek için "Bu anı, bu yalnzzhk her zaman benimle olacaktı artık: Bütün güneşlerde bu kar, bütün baharlarda bu duman..." (Semprun, 1998, s. 150) ifadelerini kullanan yazar, "kar ve dumandan oluşan parlaklı̆̆mı" (Semprun, 1998, s. 240) ilk günkü gibi koruyan geçmişin karanlığını kaleme alırken geleceğe, yaşamaya dair umudunu, doğanın insanın kötülüğünü örtücü gücünde yakalar. Nasıl ki yazmak insan eliyle oluşturulan kötülüğü anlatarak bu kötülüğe karşı mücadele edebilecek en güçlü ve kalıcı eylemse, doğa da bütün kamp alanının ve tüm kötü anıların üstünü örtebilecek yegâne güçtür. Bu doğrultuda yazar Büyük Yolculuk'ta doğanın iyileştirici gücüne ve varolma inadına duyduğu güveni ve geleceğe dair dileğini şu sözlerle aktarır:

Otlarm, çalılarm, böğürtlen ve ağaç köklerinin mevsimler boyu, Ettersberg’in o hiç dinmeyen yağmuru altında, kışın karda, ilkyaz başlayınca uğuldayan nisan güneşinde her yeri nasıl yavaşça kapladıkların, çatırdayan tahtaların, gittikçe ilerleyen gürgen ormanının dağıtıp parçaladığı çimento tozlarını arasında, yalnız doğada rastlanabilecek bir inatla, bütün bu bitkilerin durup dinlenmek bilmeden, insanlar tarafindan tepenin yamacında kurulmuş kampı nasıl örttüklerini görmek isterdim. Önce Büyük Kamp'n barakaları yıkılır, tahtalar gittikçe yükselen o ağaç ve ot denizinin güzelim yeşilinde boğulur giderlerdi (Semprun, 1985, s. 185).

Doğanın, yaşamı içeriye taşıyarak eşiğin öte tarafına geçeceği ve böylelikle ölümün simgelerini tek tek yok edeceği umudu, bu satırların yazılmasından yaklaşık otuz yıl sonra, Semprun tarafından, Yazmak ya da Yaşamak'ta bir kez daha vurgulanır. Semprun, 1992 yılında Buchenwald'e döner. Kampa dönüş, Bir Ölü Lazım başlıklı yapıtında karşısındaki tutsağa insan "kendisiyle, kendi tarihiyle ilgilenmeyi başartrsa, dünyayla da yeniden ilgilenebilir" tavsiyesinde bulunduğunu belirten yazar için hem kişisel geçmişine hem de yakın dönem siyasetine dair derin izler barındıran simgesel bir alana dönüş anlamına gelir (Semprun, 2006, s. 38). Yazarın dikkatini, tıpkı kampın tasfiyesini izleyen ilk günlerde olduğu gibi, öncelikle kuş sesleri çeker. Yazar, insana ve tarihe dair "en önemli simgesel anma ve geleceğe bakma 
yeri” (Semprun, 1998, s. 313), “anılarla dolu, alçaklğın Avrupa Tarihini yansitan [bir] arkeolojik sit alanı” (Semprun, 2006, s. 60) olan bu mekânda, yaşamın kötülüğün yok ediciliği karşısındaki gücünü ve sürekliliğini yıllar sonra, yine kuşlar aracılı̆̆ıyla bir kez daha vurgular:

Burada yirmi yaşımı doldurmuştum; yaşamım da henüz sadece bir gelecek olduğu o günlere dönmek suretiyle, yine burada tamamlanmış oluyordu.

İște o zaman kuşların neșeli cıvıltıların ișittim. Sonunda Ettersberg'e dönmüşlerdi demek... Çeşitli cıvıltılardan oluşan uğultuları bana bir okyanusun mirltısı gibi geliyordu. Ettersberg Tepesine hayat yeniden gelmişti (Semprun, 1998, ss. 302-303).

Öte yandan, 1945'teki tasfiyesinin ardından Demokratik Alman Cumhuriyeti'nin kuruluşuna (1950) kadar Sovyet güçleri tarafından kullanılmaya devam edilen kamp, 1992 yılında artık anıtsal bir özellik kazanmış ve kampın bir kısmı Semprun'un hayal ettiğinden uzak biçimde, doğadan sakınılmış ve "berbat, çirkin" bir anıt kompleksinin eşlik ettiği, "insanı altüst eden bir hatırlama, bir çağrışım yeri"ne dönüşmüştür (Semprun, 1998, ss. 302-303). Ancak, tüm anıtlaştırma çabalarına karşın anıtın karşı yamacı doğanın hakimiyetine girmiştir:

Ettersberg'e dönen kuşlarnn rengarenk cuvıltılarım işitir işitmez bir şey dikkatime çarpmışt. Yamacın eteğinde karantina olarak kullanılan Küçük Kamp’n temel yeri görünmüyordu. (...) Küçük Kamp’n yerinde yeniden orman yükselmiști. Halbwachs ve Maspero'nun öldüklerini gördüğg̈um 56’ncı bloğun yerini şimdi orman kaplyordu. 29 Ocak 1944’te geldiğim, Buchenwald’in gizlerini çözmeyi öğrenmeye, kardeşliğin sırrın keşfetmeye, Mutlak Kötülüğün ışıyan dehşetini yüz yüze seyretmeye başladı̆̆ım 62'nci bloğun yeri de öyleydi (Semprun, 1998, s. 311).

Yazmak ya da Yaşamak'ın son kısmını oluşturan "Weimar’a Dönüş" başlı̆̆ altında yer bulan bu iki karşıt görünüm, yazara, deneyiminin duygusal ağırlı̆̆ını ve aynı zamanda, anlatılarının bir diğer odağını oluşturan siyaset eleştirisini ortaya koyan bir ifade alanı sunar. Yazar bu iki karşıt görünüm aracılığıyla, unutulması olanaksız tarihsel gerçeğin ve kötülüğün insan eliyle anıtlaştırılmasının karşısına doğanın arındırıcı ve kötülükleri örtücü gücünü yerleştirir. Her ne kadar insan eliyle yaratılan kötülük yine insan eliyle anıtlaştırılmış olsa da ağaçlar, insanın aksine, kendilerini çevreleyen ve tehdit eden kötülüğ̈̈ uzaklaştırmanın ve kamp tarihinin görünür izlerini silmenin olanaklı olduğunu gösterirler:

Demek ki, tepenin bir yamacında, büyüklük şaşkını azman bir mermer anıt halka komünist rejimin Avrupa'daki anti-faşist mücadeleye bağh olduğu - sahte, çünkü sadece simgesel bir bağhllk mesajın veriyor; öteki yamacındaysa yeni bir orman komünizmin mezbahasinın üzerinde ilerleyerek, insanların belleğinden değilse bile doğanın mütevazı ama inatçı belleğinden bunun izini silmeye çalışıyordu (Semprun, 1998, s. 312).

Son olarak bu geçmişle ve Buchenwald ile yeniden yüzleşme anına, kuş cıviltılarının ve ormanın yanı sıra Aragon'un Chanson Pour Oublier Dachau şiirinin dizeleri de eşlik eder:

Vaktiyle kuşsuzdu bu orman, firınlardan çıkan mide bulandırıcı koku yüzünden kuşları kaçmış olan bu kayın ormanı..

O zaman şïrin sonunu söyledim kendi kendime:

O kadar çok insan var ki bu yeni dünyada

Onlara bir daha asla doğal gelmeyecek tatlılık

O kadar çok insan var ki şu eski dünyada

Onlar için artık yabancıdır her tür tatlılık

Kendi çocukları bile anlayamayacak onları

Oh, sen ey geçen yolcu

Uyandırma bu gece uyuyanları ... (Semprun, 1998, ss. 196-197). 
Dolayısıyla Buchenwald'e dönüş, kamp yaşamı boyunca yazarı hayatta tutmuş bütün öğeleri yeniden bir araya getirir. Kampta geçirdiği yıllarda doğaya ve sanata sığınmış, kampın tasfiyesinin ardından, kampı ziyaret eden çevre sakinlerinin riyakârlığı karşısında öfkesini ve sıkıntısını nasıl dindirdiğini "belki de, laboratuvarn önüne biriken Weimarl kadınların ağlaşmalarından kaçarak, Ettersberg”in ağaçlarla kaph öteki yamacında yüzümü ilkyaz otlarına bastırdığım an gelip beni bulan duyguydu mutluluk" sözleriyle aktarmış olan Semprun, kamptan sonraki yaşamında ve kendisine acıdan başka bir şey sunmayan yazma sürecinde de, travmaya ve belleğine direnme gücünü yine doğada ve sanatta bulmuştur (Semprun, 1985, s. 148).

Sonuç olarak Büyük Yolculuk ve Yazmak ya da Yaşamak başlıklı yapıtlar, etkisi yaşam boyu sürecek, unutulması imkansız travmatik bir deneyimi ele alan anlatılar olarak, unutma ve göreceli bir huzur ile anımsama ve iç sıkıntısının dönüşü arasında konumlanırlar (Pavis, 2016, s. 10). Söz konusu deneyimin yazıya aktarılmasının güçlüğü yazarı akıl almaz kötülüğü, "yaşantıları[yla] beslenen, ama onları aşabilen, onlara imgelemi, kurguyu da ekleyebilen bir birinci kiş̧ı"nin ağzından aktarmaya iter (Semprun, 1998, s. 175). Yapitlarda doğa "gerçekliğin gerçek görünmesine, hakikatin akla yakın gelmesine yardım edecek" bu kurgunun, diğerini kültürün oluşturduğu iki önemli kaynağından biridir (Semprun, 1998, s. 176). Anlatılarda doğa, çoklu bir role sahiptir. Bir yandan varlığı görmezden gelinemez bir evrensel gerçek oluşturan diğer yandan bakanın gözünde, deneyiminde, yorumunda, duygularında anlam kazanan doğa öncelikle, imgelemin süzgecinden geçen ve yeniden kurgulanan gerçeğin, bu gerçeği abartılı ve akıl almaz bulması olası olan okur için daha kavranabilir ve kabul edilebilir bir biçim almasını sağlar. Buna ek olarak bir yandan anlatının zamansal sınırlarını belirlerken diğer yandan döngüsel niteliği sayesinde yazarın, deneyiminin canlılı̆̆ını koruyan duygusal ağırlığını şimdiki zamanda aktarabilmesine olanak tanır. Bunun yanı sıra doğa, kamp yaşamı boyunca yazara sürekli bir dışarısı olduğunu ve bu dışarıda yaşamın devam etmekte olduğunu anımsatmış ve böylelikle tutsaklığa ve ölüme direnmesini sağlamıştır. Dolayısıyla yazarın belleğinde ayrıcalıklı bir yere sahip olmuş, yazarın yaşamını sürdürmesine yardımcı olurken içinde bulunduğu travmatik ruh halini edebiyat metnine aktarmasında bir nirengi noktası oluşturmuştur.

\section{Kaynakça}

Benestroff, C. (2010). L'écriture ou la vie, une écriture résiliente. Littérature 159, 39-52. Doi 10.3917/litt.159.0039.

Cortanze, G. (2008). Hayat Yazısı Jorge Semprun. Çev. Nükhet İzet. İstanbul: Doruk.

Gürsel, N. (1985). Jorge Semprun ve Büyük Yolculuk. Büyük Yolculuk. İstanbul: Can.

Pavis, M-C. (2016). Revenances et hantises dans les récits des camps de Jorge Semprun. Conserveries mémorielles, 18, Erişim adresi: http://journals.openedition.org/cm/2275.

Pedrol-Aguilà, M. (2016). Présence nécessaire de l'art dans L'écriture ou la vie de Jorge Semprun. Çédille, revista de estudios franceses 12, 348-367. Erişim adresi: http://cedille.webs.ull.es/12/18pedrol.pdf.

Semprun, J. (2006). Bir Ölü Lazım. Çev. Işık Ergüden. İstanbul: Can.

Semprun, J. (1998). Yazmak ya da Yaşamak. Çev. İsmet Birkan. İstanbul: Can.

Semprun, J. (1985). Büyük Yolculuk. Çev. Nedim Gürsel. İstanbul: Can.

Semprun, J. ve Wiesel, E. (1995). Se taire est impossible. Paris: Éditions Mille et une nuits.

Touret, M. (2004). "Jorge Semprun, le témoin inventif." Le roman français au tournant du XXIe siècle. Ed. Marc Dambre, Aline Mura-Brunel ve Bruno Blanckeman. Paris: Presses Sorbonne Nouvelle, 103-114. 